\title{
Chromosome studies on Brazilian cerrado plants
}

\author{
Eliana Regina Forni-Martins and Fernando Roberto Martins \\ Departamento de Botânica, Instituto de Biologia, Universidade Estadual de Campinas, Caixa Postal 6109, \\ Campinas 13083-970, SP, Brasil. Send correspondence to E.R.F.M.
}

\begin{abstract}
Cerrado is the Brazilian name for the neotropical savanna, which occurs mainly in Brazilian Central Plateau, composed of herbaceous-subshrubby and shrubby-arboreal floras, both of which are heliophilous, highly diverse and regionally differentiated. Considering species distribution and chromosome numbers, some authors have proposed that the herbaceous-subshrubby flora of the neotropical savanna is quite old, while the shrubby-arboreal flora is derived from forests, a hypothesis that implies higher chromosome numbers in the savanna than in the forest. If, however, chromosome numbers are similar in the cerrado and in forests, both could be similarly old, indicating that bi-directional flow of flora occurred in the past. This paper presents data on chromosome numbers and microsporogenesis for 20 species in 13 families collected in the States of São Paulo, Goiás and Minas Gerais, providing previously unpublished data for Myrcia (Myrtaceae), Luxemburgia (Ochnaceae) and Hortia (Rutaceae). Meiosis proved to be normal, indicating regularity in the sexual reproductive process. Chromosome numbers varied from $2 \mathrm{n}=18$ (Allamanda angustifolia: Apocynaceae) to $2 \mathrm{n}=$ ca. 104 (Ouratea spectabilis: Ochnaceae), being low $(20<2 n<30)$ in most of the species. Since similar numbers have been observed with forest species, it is not, at the moment, possible to support the hypothesis that cerrado species derived from the surrounding forests. Instead, we suggest the possibility of a bi-directional exchange of floristic elements between cerrado and forests during evolutionary time.
\end{abstract}

\section{INTRODUCTION}

Cerrado is a Brazilian word referring to the neotropical savanna occurring mainly in the Central Brazilian Plateau. The phytogeographic province in which the cerrado occurs - with an approximate area of $1.8 \times 10^{6} \mathrm{~km}^{2}$ (Sarmiento, 1983) - was given the name Oreads by Martius (1840). Coutinho (1978) considered the cerrado as a complex of different oreadic formations constituting an ecotone, varying from a completely open formation (campo limpo, grassland physiognomy) to a closed formation (cerradão, forest physiognomy), with intermediary savanna formations (campo sujo, campo cerrado and cerrado sensu stricto). Although great physiognomic variations occur, the basic physiognomic pattern, according to Heringer et al. (1977), is a relatively continuous graminoid stratum (absent in the cerradão) covered by a woody stratum with varying density of shrubs and low trees (absent in the campo limpo). The core area of the cerrado includes the States of
Goiás, Mato Grosso, Mato Grosso do Sul, Rondônia, Minas Gerais and Piauí, but disjunctions occur in the States of Paraná and São Paulo and in the Northern and Northeastern regions (Castro et al., 1999). Occupying such a large and discontinuous area, the cerrado has boundaries with different plant formations in very different phytogeographic territories. According to Sarmiento (1983), it is bounded in the north by the Amazon Forest, the northeast by the caatinga (a semi-arid region with thorn-woodland/ shrubland), the east and the south by the Atlantic Forest, and the southwest by the Pantanal Matogrossense (the inundation plain of the Paraguai River with a mosaic of vegetation varying from grassland and meadow to savanna and forest). At low altitudes the cerrado bounds with many different forest and non-forest formations, but at high altitudes it bounds almost exclusively with the campo rupestre, a rupicolous grassland/shrubland on very shallow soils, mostly on quartzite (Castro et al., 1999).

The cerrado flora is diverse, and some authors have suggested that it is composed of several hundred species (Rizzini, 1963; Heringer et al., 1977). After compiling 145 floristic surveys from 78 cerrado localities, updating the binomials, and considering the difficulties of taxonomic identification of several species, Castro et al. (1999), proposed the existence of about 1,000 to 2,000 shrubby-arboreal species and 2,000 to 6,000 herbaceous-subshrubby species. Such a high diversity is believed to be the outcome of complex evolutionary patterns, in which paleoclimatic variations and exchange of floristic elements with surrounding plant formations played a major role.

The evolution of the South American flora was influenced by events in the Cenozoic, as the impact of the Andean orogeny and climatic oscillations between the glacial and interglacial times (van der Hammen, 1974, 1988; Axelrod, 1992). It is known that both forest and savanna formations were already present in the Cenozoic, and that these formations maintained contact during evolutionary time (Sarmiento, 1983). The antiquity of the savanna is indicated by the occurrence of the same plant genera in both Africa and South America (Sarmiento, 1983), that is to say they evolved before the complete separation of the Gondwana continent, which began to occur in the late Jurassic/early Cretaceous, ca. 140 million years ago and proceeded during the angiosperm appearing and diversification (Axelrod, 1992). The first savanna was probably essentially herbaceous, or with a few woody species, and most of the sa- 
vanna shrubby-arboreal flora would have developed independently in Africa and South America (Sarmiento, 1983). The initial diversification of the savanna flora coincided with its early expansion, which is believed to have occurred in the Eocene, by 48-49 million years ago (Axelrod, 1992).

Although not explicitly mentioned, Sarmiento (1983) based his ideas on the theory of ecological refuges (Haffer, 1969; Vanzolini and Williams, 1970; Brown Jr. and Ab'Saber, 1979) when he presented his hypothesis on the contribution of the Cenozoic climatic oscillations to the origin of the cerrado shrubby-arboreal flora. Such oscillations caused variations in humidity, rainfall and temperature, provoking alternate expansions and contractions of the areas occupied sometimes by savannas and sometimes by forests. The expansion of xerophilous or hygrophilous biomes coinciding with oscillations towards drier-warmer or more humid-colder climates caused intense speciation in forests as well as in the savanna (Axelrod, 1992), and a large genetic flow would have occurred from the humid forests (Amazon and Atlantic) to the savanna over a long period, implying great speciation in the cerrado (Sarmiento, 1983). This mechanism could explain the high species richness in the cerrado, which would have acted as a center for the supply of species to other South American savanna areas (Sarmiento, 1983), and implies that most of the shrubbyarboreal flora of the cerrado is derived from the forests and, therefore, is of recent origin. Such a speciation pattern would be reflected in the current distribution of cerrado species, in which Sarmiento (1983) recognized four groups: 1) woody species belonging exclusively to the cerrado, 2) a large number of cerrado woody species that are closely related to forest species ("vicarious species" sensu Rizzini, 1963), 3) a herbaceous-subshrubby flora peculiar to the cerrado, and 4) an accessory non-woody flora with "generalist" species.

Speciation can be accomplished through different mechanisms, some of which imply an alteration of chromosome numbers between genera and closely related species, which can be due to two main processes, i.e., polyploidy (multiplication of the chromosome set) and disploidy (the increase or decrease of one, or few, chromosomes). Polyploidy is one of the most frequent and important numeric chromosome alterations occurring in the evolution of plants (Stebbins, 1971), affecting from 30 to $80 \%$ of plant species (Masterson, 1994), while in angiosperms it is estimated to be about $50 \%$, especially when we consider that species with $\mathrm{n}>11$ are polyploid (Stebbins, 1950). According to Stace (1991), two polyploid types can be recognized: a) neopolyploids, which have a more recent origin, with the original diploids or intermediary polyploids still existent, and b) paleopolyploids, which are older, and in which the related diploids are extinct.

Morawetz (1990) has postulated that the cerrado has a more recent origin than the surrounding forests if we consider the high frequency of polyploid species and the fact that in certain families (e.g., Bombacaceae and
Clusiaceae) cerrado species possess the highest chromosome numbers, while closed related species (e.g., Annona, Cochlospermum, Roupala) show higher chromosome numbers in the cerrado than in forests. Morawetz (1990) also observed polyploid cytotypes in some cerrado species (Duguetia and Kielmeyera). Stebbins (1950) postulated that a high percentage of polyploidy should be characteristic of the colder regions of high altitudes and latitudes, and Morawetz (1990) generalized the relationship between the polyploidy and restrictive environmental factors in any region by stressing the importance of the polyploidy in the speciation of tropical plants subject to extreme ecological conditions, as occur in the cerrado, mangrove swamps, and sand dunes.

Speciation mechanisms involving variation in chromosome number may be investigated not only by counting the frequency of different chromosome numbers in a flora, but also by the analysis of the regularity of the microsporogenesis, which occurs during the process of sexual reproduction. Interspecific hybrids and unbalanced polyploids, especially those with odd ploidy, generally present a high frequency of meiotic abnormalities (Stace, 1991). Bretagnolle et al. (1998) stated that, although most polyploid species are not apomitic, most apomitic species are polyploid, and many researchers, including Ferri (1960) and Rizzini and Heringer (1962), have considered that the high frequency of structures related to vegetative reproduction indicates that apomixy is predominant in the cerrado flora. However, more recent studies have shown the efficiency of the sexual reproduction in cerrado species, with pollination and dispersion (Gottsberger and Silberbauer-Gottsberger, 1983; Silberbauer-Gottsberger and Gottsberger, 1988), seed germination (Felippe and Silva, 1984; Melo et al., 1998), and seedling establishment (Válio and Moraes, 1966), all being important. Forni-Martins et al. (1992) investigated microsporogenesis in cerrado plants, and found that meiotic regularity occurred with a high frequency $(83.3 \%)$ in 18 species. The high frequency of meiotic regularity in the flora of an entire formation or formation complex, as the cerrado, could indicate that most of the numeric alterations and hybridizations that could have occurred are already stabilized, implying that the process of sexual reproduction is effective.

The hypothesis of Morawetz (1990) assumes that the increase in chromosome number is the main cause of speciation in the cerrado flora. If so, we expect high chromosome numbers to predominate in cerrado species when compared to related species in forests, indicating the derivation of the cerrado shrubby-arboreal flora. On the other hand, the widespread occurrence of high chromosome numbers in both cerrado and forest species (depending on the taxonomic group considered) could indicate a concomitant evolution of these two types of vegetation, with a bi-directional genetic flow having occurred between them during evolution, indicating that South American forests and savanna are similarly old. 
However, the simple verification of an elevated proportion of high chromosome numbers in a flora is not enough to affirm conclusively that it is derived from another flora, in which this proportion was lower, since paleopolyploid species can suffer new polyploidizations, giving rise to neopolyploid species, which can be more primitive than diploids recently speciated (Guerra, in press). Thus, to affirm conclusively that one flora is derived from another flora by higher frequency of high chromosome numbers it is necessary to have a great amount of karyological and phylogenetic data on the species of both floras. A sound knowledge of chromosome number as well as many other characteristics of many forest and savanna species is necessary to verify the consistency of the hypotheses of Sarmiento (1983) and Morawetz (1990). Karyological knowledge of tropical flora, including Brazilian flora, is not well developed, with information on many genera and even on some endemic families in Central and the South America completely lacking (Raven, 1975), and a karyological database of cerrado and forest plants is of fundamental importance to the discussion of the origin of the cerrado.

The record presented in this paper provides data on the chromosome number and evaluates the regularity of the meiotic process through the analysis of microsporogenesis of cerrado species, and compare these data with those available for Atlantic and Amazon forest species, thus contributing to the discussion of the origin of these plant formations.

\section{MATERIAL AND METHODS}

Most of the species studied were collected in the State of São Paulo (Table I), with voucher materials depos- ited in the UEC (Herbarium/Departamento de Botânica/IB/ UNICAMP). Depending on the availability of floral buds or seeds, chromosome studies were based on meiosis or mitosis, respectively. The cells in different phases of division (meiosis or mitosis) were observed with an optical microscope, interpreted and, insofar as possible, photomicrographed.

Recently germinated radicles were used in the study of mitotic chromosomes. Radicles with a length of about 1 $\mathrm{cm}$ were pretreated with paradichlorobenzene (PDB) for approximately $4 \mathrm{~h}$ at $16-18^{\circ} \mathrm{C}$, fixed in Carnoy solution (3 parts ethanol:1 part glacial acetic acid) for $24 \mathrm{~h}$, transferred to $70 \%$ ethanol, and stored in a freezer. Slides were prepared by squashing the radicle tips and applying the Giemsa technique (Guerra, 1983). To improve hydrolysis and facilitate squashing in some species, a $2.5 \%$ solution of pectinase was applied to radicles already fixed for about $1-2 \mathrm{~h}$.

For the observation of meiotic chromosomes, the floral buds were fixed in Carnoy solution $3: 1$ for $24 \mathrm{~h}$, transferred to $70 \%$ ethanol, and stored in a freezer. Cytological preparations were made by squashing the anthers in $1.2 \%$ acetic carmine (Medina and Conagin, 1964). This same technique was used to verify the normality of microspore tetrads and the viability of pollen grains. About 200 tetrads from three different floral buds and 500 pollen grains from five different flowers were examined for each species, and the average percentage of normal tetrads or pollen grains calculated.

Chromosome numbers as cited by Bolkhoviskikh et al. (1969), Moore (1973, 1974, 1977), Goldblatt (1981, 1984, 1985, 1988) and Goldblatt and Johnson $(1990,1991$, 1994, 1996, 1998) were used in this study.

Table I - Chromosome numbers of species from the cerrado and cerrado-campo rupestre (rupicolous grassland/shrubland) ecotone (marked with an asterisk ${ }^{*}$ ). Collection sites: 1-Itirapina (São Paulo State), 2-Moji Guaçu (São Paulo), 3-Moji Mirim (São Paulo),

4-Uberlândia (Minas Gerais), 5-Campinas (São Paulo, in cultivation), 6-Pirenópolis (Goiás).

\begin{tabular}{|c|c|c|c|c|}
\hline Family & Species & $\mathrm{n}$ & $2 \mathrm{n}$ & Local \\
\hline Apocynaceae & Allamanda angustifolia Pohl.* & 9 & - & 6 \\
\hline Araliaceae & Didymopanax vinosum (Cham. \& Schlecht.) March. & - & - & 1 \\
\hline \multirow[t]{2}{*}{ Bignoniaceae } & Jacaranda caroba (Vell.) DC. & 18 & - & 1 \\
\hline & Memora sp. & - & - & 1 \\
\hline Bombacaceae & Pseudobombax longiflorum (Mart. \& Zucc.) A. Robyns & & ca. 88 & 5 \\
\hline Labiatae & Eriope velutina Epling.* & 10 & - & 6 \\
\hline Lauraceae & Ocotea pulchella $(\mathrm{Nees}) \mathrm{Mez}$ & - & 24 & 1 \\
\hline Leguminosae & Stryphnodendron polyphyllum Benth. & - & ca. 26 & 1 \\
\hline Melastomataceae & Cambessedesia hilariana (A. St.-Hil. Ex Bonpl.) DC.* & ca. 21 & & 6 \\
\hline \multirow[t]{6}{*}{ Myrtaceae } & Campomanesia pubescens (A.DC.) Berg. & 11 & - & 1 \\
\hline & Eugenia aurata Berg. & 11 & - & 1 \\
\hline & Eugenia bimarginata DC. & - & 32 & 1 \\
\hline & Myrcia bella Camb. & 11 & - & 1 \\
\hline & Myrcia lingua Berg. & 11 & - & 1 \\
\hline & Psidium acutangulum DC. & - & 44 & 5 \\
\hline \multirow[t]{2}{*}{ Ochnaceae } & Luxemburgia speciosa St.-Hil.* & 8 & - & 6 \\
\hline & Ouratea spectabilis (Mart.) Engl. & ca. 52 & - & 1 \\
\hline Rutaceae & Hortia brasiliensis Vand. ex DC. & 12 & - & 4 \\
\hline Sapindaceae & Talisia angustifolia Radlk. & - & 32 & 1 \\
\hline Sapotaceae & Pouteria torta (Mart.) Radlk. & 14 & - & 3 \\
\hline
\end{tabular}




\section{RESULTS}

Chromosome numbers varied greatly between species, with the lowest being found in Allamanda angustifolia $(2 \mathrm{n}$ $=18)$ and the highest in Ouratea spectabilis $(2 \mathrm{n}=$ ca. 104) and Pseudobombax longiflorum $(2 \mathrm{n}=$ ca. 88$)$, with most of the species presenting low chromosome numbers of about $2 \mathrm{n}=20-30$ (Table I, Figures 1 and 2).

The chromosomes of the species studied were in general quite small, e.g., in Talisia angustifolia most of the chromosomes measured 1.0-2.1 $\mu \mathrm{m}$, while in Psidium acutangulum they varied from $1.5-2.0 \mu \mathrm{m}$, with some chromosomes of this species showing a medium centromeric position (Figure 1F).

Meiosis was mostly regular, with normal chromosome pairing in the different stages of prophase I and regular disjunction in anaphase I and II. No atypical meiotic figure was observed in the process of chromosome disjunction.

In Eriope velutina, although chromosome disjunction was normal in meta-anaphase II, $1 \%$ of the microspore tetrads presented a micronucleus (Figure 2D). About $4 \%$ of Ouratea spectabilis tetrads showed abnormalities, and, al-
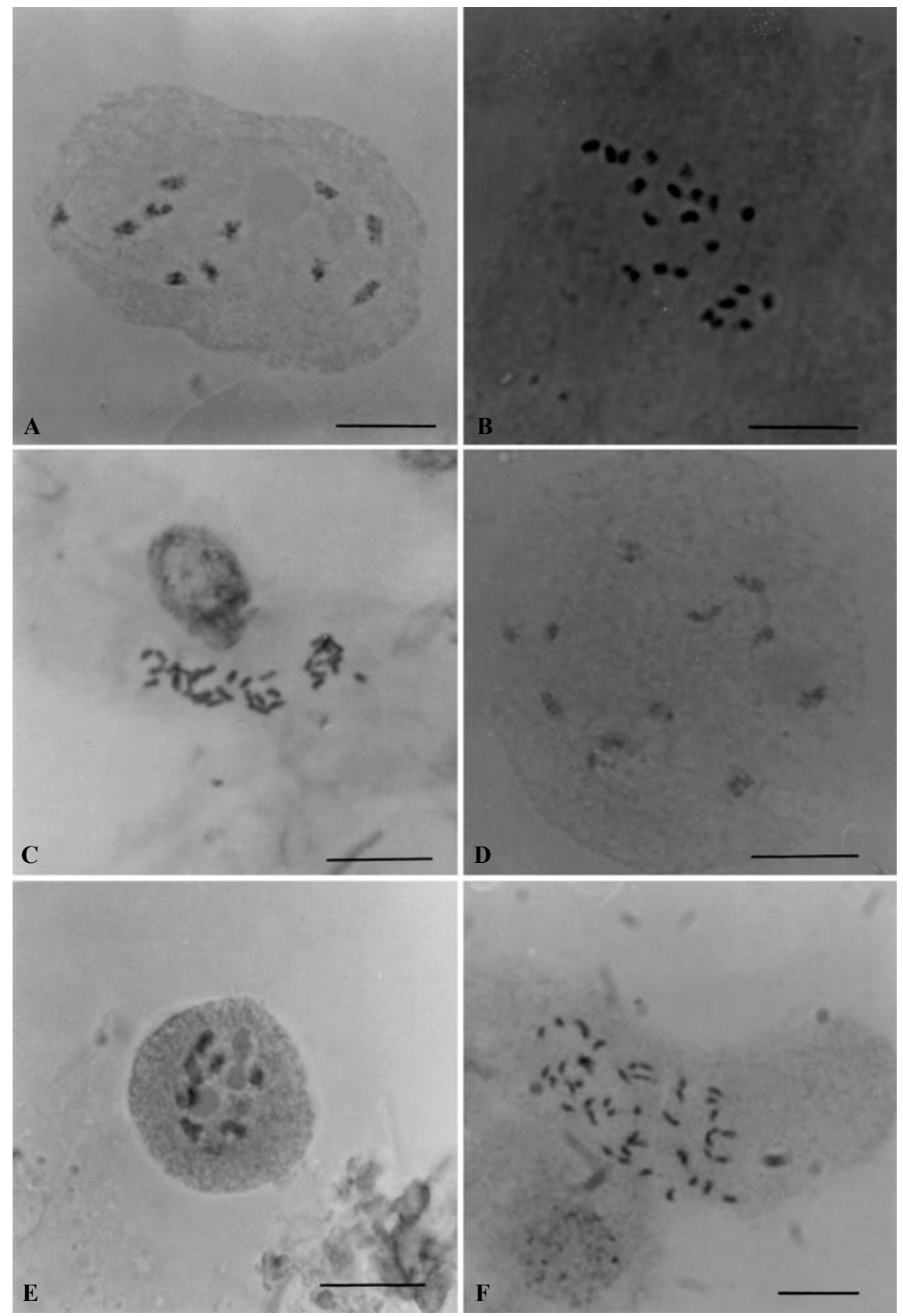

Figure 1 - Chromosomes of cerrado species belonging to the family Myrtaceae: A) Campomanesia pubescens ( $\mathrm{n}=11)$, B) Eugenia aurata $(2 \mathrm{n}=22)$, C) E. bimarginata $(2 \mathrm{n}=32)$, D) Myrcia bella $(\mathrm{n}=11)$, E) M. lingua $(\mathrm{n}=11)$ and $\mathbf{F})$ Psidium acutangulum $(2 \mathrm{n}=44)$. Bar $=10 \mu \mathrm{m}$. 
though it was not possible to count the chromosomes of Memora sp., a small proportion (4\%) of abnormal tetrads was observed in this species, while about $25 \%$ of pollen grains in Didimopanax vinosum presented an irregularly small size.

\section{DISCUSSION}

\section{Chromosome numbers}

Table I shows the variation in chromosome number of various cerrado species, similar to the variation found by Forni-Martins et al. (1995) in a group of 20 other species, in which the minimum chromosome number was $2 n=16$ for Xylopia aromatica (Annonaceae) and Styrax ferrugineus (Styracaceae). In both cases some chromosome numbers were the same in different families and genera, and mostly varied between $2 n=20-30$, e.g., $2 n=22$ was observed in three genera of Myrtaceae (Table I) as well as by Forni-Martins et al. (1995) for Andira humilis (Leguminosae) and Alibertia sessilis (Rubiaceae). This variation in chromosome numbers is similar to that reported by Coleman (1982) and Gibbs and Ingram (1982) for some cerrado species in the State of São Paulo. Bandel (1974) studied 35 leguminous cerrado species whose chromosome numbers varied between $2 n=16-26$, with only one species of Mimosa presenting $2 \mathrm{n}=52$. Based on the studies so far conducted, it appears that low chromosome numbers predominate in cerrado species, presumably because they have originated from non-polyploid stocks by one or two polyploidization cycles $(2 n>22$ or $2 n>44)$, according to the concept of Stebbins (1950).

Greater differences occur, however, when one considers the species with the highest chromosome numbers. Forni-Martins et al. (1995) observed $2 \mathrm{n}=$ ca. 270 for Eriotheca pubescens and $2 \mathrm{n}=92$ for $E$. gracilipes, while we observed $2 \mathrm{n}=$ ca. 104 in Ouratea spectabilis and $2 \mathrm{n}=$ ca. 88 in Pseudobombax longiflorum (Table I), and it is worth noting that E. pubescens, E. gracilipes and $P$. longiflorum belong to the family Bombacaceae, which is characterized by having high chromosome numbers (Gibbs et al., 1988). From the studies so far done it may be noticed that species with very high chromosome number sum up a little proportion of the cerrado shrubby-arboreal flora, and that their chromosome numbers are very different, which could indicate that these species originated from stocks that were already polyploid or suffered many polyploidization cycles.

The chromosome numbers of species of the genera Myrcia, Luxemburgia and Hortia have not before been recorded in the literature, and are an important contribution to the discussion of the taxonomic and evolutionary relationships between these groups. It is interesting to note that the chromosome number we observed in Hortia $(\mathrm{n}=12)$

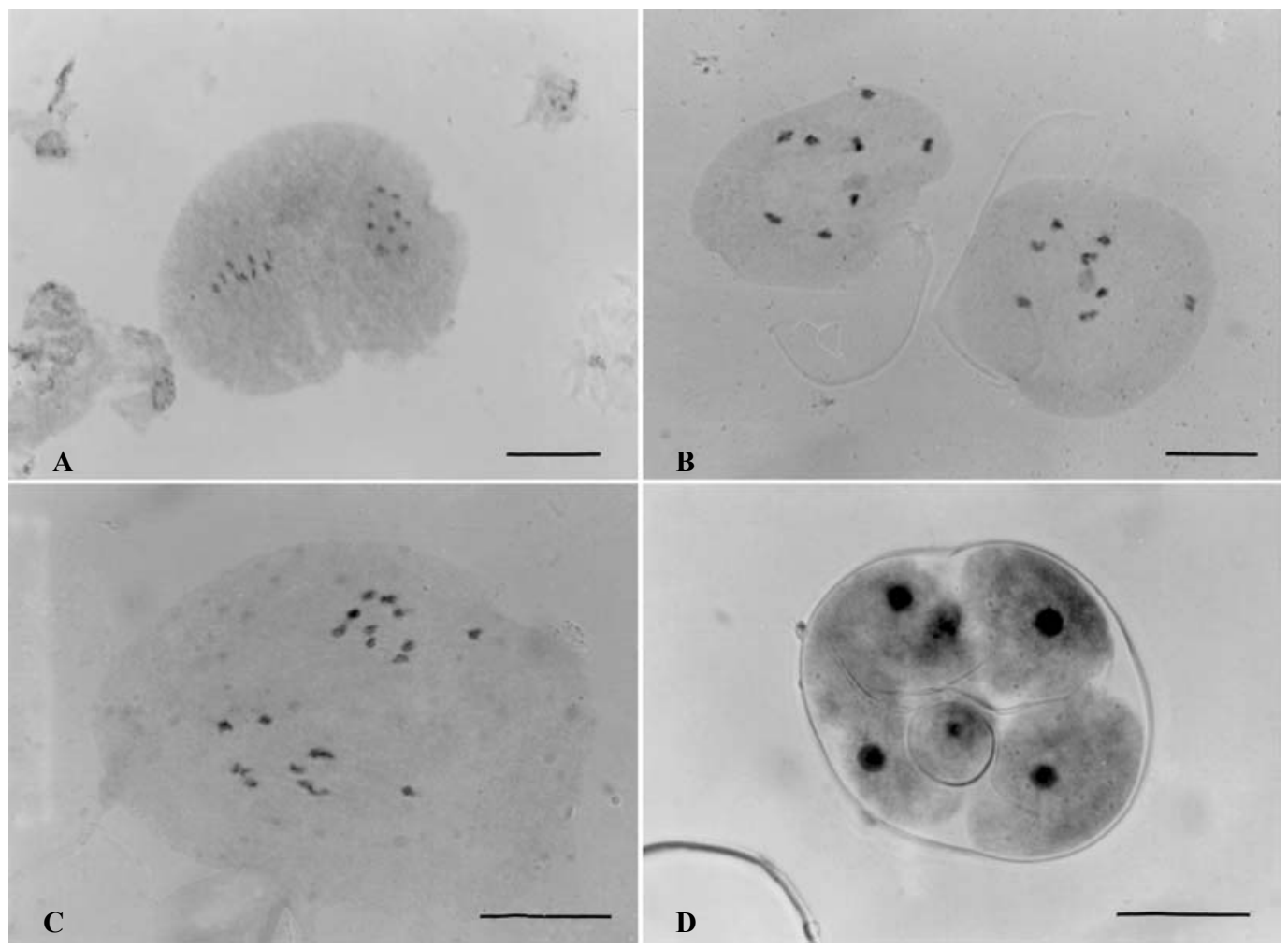

Figure 2 - Chromosomes and microspore tetrade of species from the cerrado-campo rupestre ecotone. A) Apocynaceae: Allamanda angustifolia $(\mathrm{n}=9)$, B) Ochnaceae: Luxemburguia speciosa $(\mathrm{n}=8)$, C) Labiatae: Eriope velutina $(\mathrm{n}=10)$, and D) same, tetrade with additional micronucleus. Bar $=10 \mu \mathrm{m}$. 
differs from the basic number $(\mathrm{x}=9)$ found in the family Rutaceae and in the tribe Toddalieae, to which this genus belongs. Rutaceae has great number of genera and species, and our results seem to confirm the need for taxonomic revision in this group, as has been suggested both by Waterman (1975), who studied the distribution of alkaloids, and Guerra (1987), who analyzed the pattern of interphasic nuclei in this family.

The analysis of individuals from different populations of the same species is also very important, as there are reports of significant variation in chromosome numbers among the populations. Morawetz (1984) found three different chromosome races $(2 \mathrm{n}=16,24$ and 32$)$ in three different populations of the typical cerrado species $D u$ guetia furfuracea, and, although the populations were geographical and ecologically separated, no taxonomically significant variation was observed. Another possible species with chromosome races is Cambessedesia hilariana, firstly studied by Almeda (1997), who found $n=23$. We found a number of chromosomes around $n=21$, as it was impossible to determine with exactitude due to the very small size of the chromosomes. Both populations studied by Almeda (1997) and by us were located in a campo rupestrecerrado ecotone in Goiás State, but as Almeda (1997) did not inform the exact locality where the species was collected, we cannot say how much apart the populations were. Different chromosome numbers may be related to particular ecological conditions to which the populations are adapted, and in the campo rupestre-cerrado ecotone these vary very much in short distances.

The chromosome counts shown in Table I confirmed previous reports for Pseudobombax longiflorum and Campomanesia pubescens, and coincided with results found for other species, e.g. Allamanda (Datta and Bhattacharya, 1981; Laan and Arends, 1985), Eriope (Harley, 1976; Coleman, 1982), Stryphnodendrum (Bandel, 1974) and Talisia (Carvalheira et al., 1991; Lombello and ForniMartins, 1998). Table I also shows that the chromosome number differed from that cited for other species in the genus, as in the case of Pouteria torta $(2 n=28)$. We present the first report for this species, whose number coincides with that observed by Goldblatt (1991) for P. laevigata and $P$. pariry $(2 \mathrm{n}=28)$, although for $P$. obovata the reported chromosome number is $2 \mathrm{n}=26$ (Ono, 1977). It seems that several species of Ouratea present $\mathrm{n}=12$ (Farron, 1957, 1963 ) or $\mathrm{n}=13$ (Bawa, 1973). The species we studied, $O$. spectabilis, is highly polyploid $(\mathrm{n}=\mathrm{ca} .52)$, being an octoploid that started from $n=13$. Knowledge of chromosome number of different species in a genus is fundamental to evaluate the relative importance of polyploidy and disploidy in its evolution.

The chromosome number of $E$. bimarginata $(2 \mathrm{n}=$ ca. 32) indicates triploidy $(3 x=33)$ followed by the loss of a chromosome, as suggested by the fact that the basic chromosome number for the family Myrtaceae is $\mathrm{x}=11$ (Atchinson, 1947), which has been observed in almost all the genera of this family so far studied, although complementary studies are necessary to understand why this atypical chromosome number exists in this family.

\section{Microsporogenesis and sexual reproduction}

The low frequency of meiotic abnormalities agrees with that presented by Forni-Martins et al. (1992), in which irregularities were observed in only three out of 18 cerrado species analyzed. We observed abnormalities in tetrads or pollen grains in just four out of 17 species (Table I), while if we include all the species so far studied (35), then 28 $(80 \%)$ showed no meiotic abnormalities. This finding confirms the theory that the sexual process seems to be as important to the reproduction of cerrado species as the underground structures related to vegetative propagation. The predominantly normal microsporogenesis weakens the initial idea that only exceptionally do cerrado plants reproduce by sexual processes (Ferri, 1960; Rizzini and Heringer, 1962). Hoffmann (1998) tested the effect of fire on reproductive potential in six typical woody cerrado species, and found that the fire reduced sexual reproduction in five species by destroying reproductive structures and seeds immediately and, in the following years, reducing the production of seeds and the size of individual plants. Hoffmann (1998) concluded that when the cerrado is frequently burnt the vegetative reproduction could be more successful than sexual reproduction. The frequency of meiotic abnormalities in forest species is similar to that found in cerrado species, as has been observed in studies in progress in the Laboratory of Biosystematics of the Departamento de Botânica of UNICAMP.

\section{High chromosome numbers and the origin of the cerrado flora}

The occurrence of species with $n>11$ in cerrado confirms that increase in the number of chromosomes is an important step in the evolution of tropical plants (Morawetz, 1986). However, the supposition of Morawetz (1990) that the cerrado has a more recent origin than the surrounding forests based on the occurrence of high chromosome numbers in cerrado species still cannot be corroborated. We stress the following arguments.

1) About 90 cerrado species have had their chromosome number so far determined. Castro et al. (1999) suggested that there are 1,000-2,000 shrubby-arboreal species and 2,000-6,000 herbaceous-subshrubby species. Hence, the species with known chromosome number sum up to only about $3 \%$ of the minimum estimative of 3,000 angiosperm species in the cerrado.

2) The evident polyploidization observed in cerrado species cannot be directly considered as an indication of their derivation from forest species, because there is not enough knowledge of the phylogenetic relationships between them. For example, the occurrence of octopolyploidy 
in Ouratea spectabis $(2 \mathrm{n}=$ ca. 104$)$, a typical cerrado species, cannot be used to support the hypothesis of Morawetz (1990). Ouratea castaneifolia $(2 \mathrm{n}=26)$, typical of forests, shows no morphologic affinity with $O$. spectabilis (Yamamoto, K., personal communication). This example reinforces the statement that polyploids cannot always be considered derived in relation to other diploid species of the same genus.

3) High chromosome numbers also occur in forest species. It seems more probable that the polyploidy frequency observed in a plant formation is related to its floristic composition, because:

a) There are families of plants that possess characteristically high chromosome numbers, as is the case of the Bombacaceae. The chromosome numbers vary from $2 n=$ 72 or 2n $=88$ in Ceiba and Chorisia, which occur in forests (Baker and Baker, 1968; Gibbs et al., 1988), up to 2n = ca. 270 (Forni-Martins et al., 1995) or $2 \mathrm{n}=276$ (Oliveira et al., 1992) in Eriotheca pubescens, typical of the cerrado.

b) Meliaceae has very few species in the cerrado (Castro et al., 1999) and many species in forests, but several species have high chromosome numbers (Styles and Vosa, 1971; Pennington and Styles, 1975). Forni-Martins, E.R. (unpublished data) observed variation of $2 \mathrm{n}=50$ in Trichilia clausenii and T. pallida up to $2 \mathrm{n}=\mathrm{ca} .100$ in Guarea macrophylla, collected from a semideciduous forest in the municipality of Campinas, São Paulo State.

c) There is a great range of chromosome numbers in some families, which have species with different ploidy levels, a typical example being Malpighiaceae, where most of its neotropical species have chromosome numbers in multiples of 10. Polyploid series (neopolyploids) have been as frequently observed in forest species (Mascagnia spp.) as in cerrado species (Banisteriopsis spp.) (Lombello and Forni-Martins, 1999).

4) A high chromosome number does not always indicate derivation, because, besides the paleopolyploids, the disploidy - which can increase or reduce the chromosome number - should also be considered. Thus, a disploid species with smaller chromosome number can be derived in relation to another with more chromosomes, and an entire taxonomic group can speciate through disploidy. Lombello and Forni-Martins (1998) showed that the derivation of the climber habit from bushes and trees in Sapindaceae processed predominantly through decreasing disploidy. It is still necessary to consider that not always the speciation implies in numerical alteration of chromosomes, for species can differ through genetic or structural alterations of the chromosomes (Stebbins, 1971).

In spite of the few karyological data available for the cerrado and forests in Brazil, so far the hypothesis of the derivation of the cerrado flora by an increase in chromosome number seems not to hold. Since high chromosome numbers and a high frequency of meiotic regularity happen as much in the forest as in the cerrado, it might also be possible that the origin of both types of vegetation was concomitant and diversification occurred with a bi-directional genetic flow between the forests (Atlantic and Amazon) and the cerrado. Such a bi-directional flow would be due to the movement of genetic stocks from the forests to the cerrado and from the cerrado to the forests, with speciation in each environment under the influence of the alternate expansion and contraction of these formations. The amplification of the inventory of chromosome numbers in cerrado and forest species may shed new light on the discussion of the origin of the cerrado flora.

\section{ACKNOWLEDGMENTS}

We would like to thank the Conselho Nacional de Desenvolvimento Científico e Tecnológico (CNPq) for the financial support, as well as the Instituto Florestal and the Instituto de Botânica do Estado de São Paulo for allowing the collection of botanical material in the conservation units and Dr. Ana Angélica A. Barbosa (Universidade Federal de Uberlândia) for collecting Hortia brasiliensis. Publication supported by FAPESP.

\section{RESUMO}

Cerrado é a palavra que, no Brasil, designa a savana neotropical, com área nuclear no Planalto Central, constituída de uma flora herbáceo-subarbustiva e outra arbustivo-arbórea, ambas heliófilas, altamente diversificadas e regionalmente diferenciadas. Considerando a distribuição de espécies e de números cromossômicos, alguns autores propuseram que a flora herbáceosubarbustiva da savanna neotropical seria bastante antiga, enquanto a flora arbustivo-arbórea seria derivada das florestas Atlântica e Amazônica, uma hipótese que implica na ocorrência de números cromossômicos mais altos no cerrado que nas florestas. Porém, se os números cromossômicos forem similares no cerrado e nas florestas, ambos os tipos de formação poderiam ser similarmente antigos, indicando que um fluxo florístico bidirecional entre o cerrado e as florestas teria ocorrido no passado. Este trabalho apresenta dados sobre números cromossômicos e microsporogênese de 20 espécies em 13 famílias, coletadas nos estados de São Paulo, Goiás e Minas Gerais, trazendo informações inéditas para Myrcia (Myrtaceae), Luxemburgia (Ochnaceae) e Hortia (Rutaceae). A meiose mostrou-se normal, indicando regularidade no processo reprodutivo sexual. Os números cromossômicos variaram de $2 \mathrm{n}=$ 18 (Allamanda angustifolia: Apocynaceae) a 2n = ca. 104 (Ouratea spectabilis: Ochnaceae), sendo baixos $(20<2 \mathrm{n}<30)$ na maioria das espécies. Como números cromossômicos similares têm sido encontrados também em espécies florestais, torna-se impossível, no momento, corroborar a hipótese de que espécies arbustivo-arbóreas do cerrado sejam derivadas de espécies das florestas limítrofes. Sugerimos que tenha havido uma troca bidirecional de elementos entre o cerrado e as florestas durante o tempo evolutivo.

\section{REFERENCES}

Almeda, F. (1997). Chromosome numbers and their evolutionary significance in some neotropical and paleotropical Melastomataceae. BioLlania 6: 167-190. 
Atchinson, E. (1947). Chromosome numbers in the Myrtaceae. Am. J. Bot. 34: $159-164$.

Axelrod, D.I. (1992). Climatic pulses, a major factor in legume evolution. In: Advances in Legume Systematics. Part 4. The Fossil Record (Herendeen, P.S. and Dilcher, D.L., eds.). Royal Botanic Gardens, Kew, pp. 259-280.

Baker, H.G. and Baker, I. (1968). Chromosome numbers in the Bombacaceae. Bot. Gaz. 129: 294-296.

Bandel, G. (1974). Chromosome numbers and evolution in the Leguminosae. Caryologia 27: 17-32.

Bawa, K.S. (1973). Chromosome numbers of tree species of the lowland tropical community. J. Arnold Arbor. Harv. Univ. 54: 422-434.

Bolkhoviskikh, Z., Grif, V., Matvejeva, T. and Zakharyeva, O. (1969). In: Chromosome Numbers of Flowering Plants (Fedorov, A.A., ed.). V.L. Komarov Botanical Institute, Academy of Sciences of the USSR, Moscow.

Bretagnolle, F., Felber, F., Calame, F.G. and Küpfer, P. (1998). La polyploïdie chez les plantes. Bot. Helv. 108: 5-37.

Brown Jr., K.S. and Ab'Saber, A.N. (1979). Ice-Age Forest Refuges and Evolution in the Neotropics: Correlation of Paleoclimatological, Geomorphologic and Pedological Data with Modern Biological Endemism. Paleoclimas 5. Instituto de Geografia, Universidade de São Paulo, São Paulo.

Carvalheira, G.M.G, War, M., Santos, G.A., Andrade, V.C. and Farias, M.C.A. (1991). Citogenética de angiospermas coletadas em Pernambuco - IV. Acta Bot. Bras. 5: 37-51.

Castro, A.A.J.F., Martins, F.R., Tamashiro, J.Y. and Shepherd, G.J. (1999). How rich is the flora of Brazilian cerrados? Ann. MO Bot. Gard. 86: 192224.

Coleman, J.R. (1982). Chromosome numbers of angiosperms collected in the State of São Paulo. Rev. Bras. Genet. V: 533-549.

Coutinho, L.M. (1978). O conceito de Cerrado. Rev. Bras. Bot. 1: 17-23.

Datta, R. and Bhattacharya, G. (1981). Role of altered karyotype in varietal differentiation in Allamanda cathartica. Linn. Proc. Indian Sci. Congr. Assoc. 68 (Sect. VI): 74.

Farron, C. (1957). Première contribution à la cytologie des Ouratea d'Áfrique occidentale française. Ber. Schweiz. Bot. Ges. (Bull. Soc. Bot. Suisse) 67:26-32.

Farron, C. (1963). Contribution à la taxinomie des Ourateae Engl. (Ochacées). Ber. Schweiz. Bot. Ges. (Bull. Soc. Bot. Suisse) 73: 196-217.

Felippe, G.M. and Silva, J.C.S. (1984). Estudos de germinação em espécies de cerrado. Rev. Bras. Bot. 7: 157-163.

Ferri, M.G. (1960). Nota preliminar sobre a vegetação do cerrado em Campo Mourão, Paraná. Bol. Fac. Filos. Ciênc. Let. USP 247, Ser. Bot. 17: 109115 .

Forni-Martins, E.R., Pinto-Maglio, C.A.F. and Cruz, N.D. (1992). Biologia da reprodução em plantas de cerrado. Anais do VIII Congresso da Sociedade Botânica de São Paulo, pp. 77-82.

Forni-Martins, E.R., Pinto-Maglio, C.A.P. and Cruz, N.D. (1995). Chromosome numbers in Brazilian cerrado plants. Rev. Bras. Gen. 18: 281-288.

Gibbs, P.E. and Ingram, R. (1982). Chromosome numbers of some Brazilian flowering plants. Not. RBG Edinb. 40: 399-407.

Gibbs, P.E., Semir, J. and Cruz, N.D. (1988). The proposal to unite the genera Chorisia Kunth and Ceiba Miller (Bombacaceae). Not. RBG Edinb. 45: 125-136.

Goldblatt, P. (Ed.) (1981). Index to chromosome numbers 1975-1978. Monographs in Systematic Botany from the Missouri Botanical Garden. V.5. Missouri Botanical Garden, Saint Louis.

Goldblatt, P. (Ed.) (1984). Index to plant chromosome numbers 1979-1981. Monographs in Systematic Botany from the Missouri Botanical Garden. V.8. Missouri Botanical Garden, Saint Louis.

Goldblatt, P. (Ed.) (1985). Index to plant chromosome numbers 1982-1983. Monographs in Systematic Botany from the Missouri Botanical Garden. V.13. Missori Botanical Garden, Saint Louis.

Goldblatt, P. (Ed.) (1988). Index to plant chromosome numbers 1984-1985. Monographs in Systematic Botany from the Missouri Botanical Garden. V.23. Missouri Botanical Garden, Saint Louis.

Goldblatt, P. (1991). In: Johnson, M. Cytology. In: The Genera of Sapotaceae (Pennington, T.D., ed.). Royal Botanic Gardens, Kew, pp. 15-22.

Goldblatt, P. and Johnson, D.E. (Ed.) (1990). Index to plant chromosome numbers 1986-1987. Monographs in Systematic Botany from the Missouri Botanical Garden. V.30. Missouri Botanical Garden, Saint Louis.
Goldblatt, P. and Johnson, D.E. (Ed.) (1991). Index to plant chromosome numbers 1988-1989. Monographs in Systematic Botany from the Missouri Botanical Garden. V.40. Missouri Botanical Garden, Saint Louis.

Goldblatt, P. and Johnson, D.E. (Ed.) (1994). Index to plant chromosome numbers 1990-1991. Monographs in Systematic Botany from the Missouri Botanical Garden. V.50. Missouri Botanical Garden, Saint Louis.

Goldblatt, P. and Johnson, D.E. (Ed.) (1996). Index to plant chromosome numbers 1992-1993. Monographs in Systematic Botany from the Missouri Botanical Garden. V.58. Missouri Botanical Garden, Saint Louis.

Goldblatt, P. and Johnson, D.E. (Ed.) (1998). Index to plant chromosome numbers 1994-1995. Monographs in Systematic Botany from the Missouri Botanical Garden. V.69. Missouri Botanical Garden, Saint Louis.

Gottsberger, G. and Silberbauer-Gottsberger, I. (1983). Dispersal and distribution in the cerrado vegetation of Brazil. Sodderbd. Naturwiss. Ver. Hamburs 7:315-352.

Guerra, M. (1983). O uso do Giemsa em citogenética vegetal - comparação entre a coloração simples e o bandeamento. Ciênc. e Cult. 35: 190-193.

Guerra, M. (1987). Cytogenetics of Rutaceae IV. Structure and systematic significance of interphase nuclei. Cytologia 52: 213-222.

Guerra, M. (2000). Chromosome number variation and evolution in monocots. 2nd International Conference on the Comparative Biology of the Monocotyledons. Royal Botanic Gardens, Sydney (in press).

Haffer, J. (1969). Speciation in Amazonian forest birds. Science 165: 131-137.

Harley, R.M. (1976). The review of Eriope and Eriopidion (Labiatae). Hooker's Ícones Plantarum. Royal Botanic Gardens, Kew, V. xxxviii, Part III.

Heringer, E.P., Barroso, G.M., Rizzo, J.A. and Rizzini, T. (1977). A flora do cerrado. In: IV Simpósio sobre o Cerrado: Bases para a Utilização Agropecuária. Ed. Itatiaia, Belo Horizonte, Editora da Universidade de São Paulo, São Paulo, pp. 211-232.

Hoffmann, W.A. (1998). Post-burn reproduction of woody plants in the neotropical savanna: the relative importance of sexual and vegetative reproduction. J. App. Ecol. 35: 422-433.

Laan, F.M. van der and Arends, J.C. (1985). Cytotaxonomy of Apocynaceae. Genetica 68: 3-35.

Lombello, R.A. and Forni-Martins, E.R. (1998). Chromosomal studies and evolution in Sapindaceae. Caryologia 51: 81-93.

Lombello, R.A. and Forni-Martins, E.R. (1999). Citologia de 15 espécies de Malpighiaceae Juss. I Simpósio Latino-Americano de Citogenética e Evolução de Plantas, Recife, PE, Programa e Resumos: 18.

Martius, C.F.P. von (1840). Tabulae physiognomicae. Brasiliae regionis iconibus expressae. In: Flora Brasiliensis (Martius, C.F.P. von, Endlicher, S., Eichler, A.G. and Urban, J., eds.). Lipsae apud Frid. Fleischer in Comm., Munich. V.1, Tomus 1, pp. 1-110.

Masterson, J. (1994). Stomatal size in fossil plants: evidence for polyploidy in majority of angiosperms. Science 264: 421-424.

Medina, D.M. and Conagin, C.H.T.M. (1964). Técnica Citológica. Publicação No. 2610. Instituto Agrônomico, Campinas.

Melo, J.T., Silva, J.A., Torres, R.A.A., Silveira, C.E.S. and Caldas, L.S. (1998). Coleta, propagação e desenvolvimento inicial de espécies de cerrado. In: Cerrado: Ambiente e Flora (Sano, S.M. and Almeida, S.P., eds.). Embrapa, Planaltina, pp. 195-243.

Moore, R.J. (Ed.) (1973). Index to Plant Chromosome Numbers for 19671971. Oosthoek's Uitgeversmaatschappij B.V., Utrecht.

Moore, R.J. (Ed.) (1974). Index to Plant Chromosome Numbers for 1972. Oosthoek, Utrecht.

Moore, R.J. (Ed.) (1977). Index to Plant Chromosome Numbers for 19731974. Oosthoek, Utrecht.

Morawetz, W. (1984). Karyological races and ecology of Brazilian Duguetia furfuraceae compared with aromatic Xylopia (Annonaceae). Flora 175: 195-209.

Morawetz, W. (1986). Remarks on karyological differentiation patterns in tropical woody plants. Plant Syst. Evol. 152: 49-100.

Morawetz, W. (1990). Accumulation of polyploid species in the cerrado vegetation of Brazil as compared with the surrounding forests. In: VIII Congresso da Sociedade Botânica de São Paulo, Campinas, 1990. Programas e Resumos: 49.

Oliveira, P.E., Gibbs, P.E., Barbosa, A.A. and Tavaleras, S. (1992). Contrasting breeding systems in two Eriotheca (Bombacaceae) species of the Brazilian cerrados. Pl. Syst. Evol. 179: 207-219.

Ono, M. (1977). Cytotaxonomical studies on the flowering plants endemic to 
the Bonin Islands. Mem. Nat. Sci. Mus. 10: 63-80.

Pennington, T.D. and Styles, B.T. (1975). The generic monograph of the Meliaceae. Blumea 22:419-450.

Raven, P. (1975). The bases of angiosperm phylogeny: Cytology. Ann. MO Bot. Gard. 62: 724-764.

Rizzini, C.T. (1963). A flora do cerrado - análise florística das savanas centrais. In: I Simpósio sobre o Cerrado (Ferri, M.G., coord.). Ed. Univ. São Paulo, São Paulo, pp. 125-177.

Rizzini, C.T. and Heringer, E.P. (1962). Studies of the underground organs of trees and shrubs from southern Brazil savannas. An. Acad. Braz. Cienc. 34: 235-247.

Sarmiento, G. (1983). The savannas of tropical America. In: Tropical Savannas (Bourlière, F., ed.). Ecosystems of the World 13. Elsevier, Amsterdam, pp. $245-288$.

Silberbauer-Gottsberger, I. and Gottsberger, G. (1988). A polinização de plantas de cerrado. Rev. Bras. Biol. 48: 651-663.

Stace, C.A. (1991). Plant Taxonomy and Biosystematics. 2nd edn. Edward Arnold, London.
Stebbins, G.L. (1950). Variation and Evolution in Plants. Columbia Univ. Press, New York.

Stebbins, G.L. (1971). Chromosomal Evolution in Higher Plants. Edward Arnold, London.

Styles, B.T. and Vosa, C.G. (1971). Chromosome numbers in the Meliaceae. Taxon 20: 485-499.

Válio, I.F.M. and Moraes, V. (1966). Sobre o sistema reprodutivo de plantas dos Cerrados. - II Simpósio sobre o cerrado. An. Acad. Bras. Cienc. 38 (Suppl.): 219-224.

Van der Hammen, T. (1974). The pleistocene changes of vegetation and climate in tropical South America. J. Biogeogr. 1: 3-26.

Van der Hammen, T. (1988). The tropical flora in historical perspective. Taxon 37: $515-518$

Vanzolini, P.E. and Williams, E.E. (1970). South American anoles: the geographic differentiation and evolution of the Anolis chrysolepis species group (Sauria, Iguanidae). Arch. Zool. 19: 1-124.

Waterman, P.G. (1975). New combinations in Zanthoxylum L. Taxon 24: 361366. 
